\title{
New methods for the isolation of Legionella pneumophila
}

\author{
PW GREAVES \\ From the Department of Microbiology and Public Health Laboratory, University Hospital, Queen's \\ Medical Centre, Nottingham NG7 2UH, UK
}

SUMMARY Some new methods for the isolation of Legionella pneumophila are described which have been successful in recovering this organism from $6 / 10$ patients with clinical evidence of Legionnaires' disease. The increased sensitivity of these methods combined with speedier isolation of the organisms than has hitherto been possible will hopefully lead to eventual isolation of this organism as a routine procedure in diagnostic microbiology laboratories.

During the summer of 1976 an outbreak of acute respiratory illness developed among delegates who had attended an American Legion Convention at the Bellevue-Stratford Hotel in Philadelphia. ${ }^{1}$ This illness, a severe pneumonia, was almost immediately called Legionnaires' disease and has been the subject of considerable study since that time. ${ }^{2} 3$ Early attempts to isolate the causal agent by conventional bacteriological methods were unsuccessful, and initial isolates of a bacterium were obtained by methods more applicable to the culture of Rickettsiae. ${ }^{4}$ These organisms, now provisionally known as Legionella pneumophila, ${ }^{5}$ were later shown to grow on Mueller-Hinton agar containing $1 \%$ haemoglobin and $2 \%$ IsoVitalex, ${ }^{6}$ the active components of which proved to be iron salts, preferably soluble ferric pyrophosphate, and L-cysteine hydrochloride. This finding led to the description of two further culture media, FG and CYE agar, which were reported to be suitable for the isolation of Legionella. ${ }^{6}$

All of these media were found to be unsatisfactory in our hands. They failed to support growth of the organism when small numbers were present, and most strains grew only slowly, individual colonies taking between seven and 10 days to develop. We therefore described a further culture medium containing blood, iron salts, and cysteine, which was more sensitive and on which the bacteria were readily visible after three days' incubation. ${ }^{7}$

Other work in this laboratory has since led to the development of additional media and methods which have proved useful for the isolation of

Received for publication 3 December 1979

Legionella from clinical specimens and which are described here.

\section{Culture media}

ENRICHED BLOOD AGAR

Blood agar base No. 2 (Oxoid) $40 \mathrm{~g}$

L-cysteine $\mathrm{HCl} . \mathrm{H}_{2} \mathrm{O} \quad 0.4 \mathrm{~g}$

$\mathrm{Fe}_{4}\left(\mathrm{P}_{2} \mathrm{O}_{7}\right)_{3}$ (soluble) $\quad 0.25 \mathrm{~g}$

Deionised water 1 litre

The ingredients are dissolved in hot deionised water and the $\mathrm{pH}$ is adjusted to 6.9 if necessary.

After sterilisation, by autoclaving at $121^{\circ} \mathrm{C}$ for $15 \mathrm{~min}$, the medium is cooled to $55^{\circ} \mathrm{C}$, and $50 \mathrm{ml}$ sterile defibrinated horse blood is added.

SELECTIVE BLOOD AGAR

Basal medium as above with:

Colistin

Vancomycin

Trimethoprim

Amphotericin B

ENRICHMENT BROTH

Proteose peptone (Difco)

Yeast extract (Difco)

Liver extract (Panmede)

Sodium chloride

L-cysteine $\mathrm{HCl} . \mathrm{H}_{2} \mathrm{O}$

$\mathrm{Fe}_{4}\left(\mathrm{P}_{2} \mathrm{O}_{7}\right)_{3}$ (soluble)

Deionised water

The ingredients are dissolved in hot deionised water and the $\mathrm{pH}$ is adjusted to 6.9.

The medium is sterilised by autoclaving at $121^{\circ} \mathrm{C}$ for $15 \mathrm{~min}$, and, after cooling to $55^{\circ} \mathrm{C}, 50 \mathrm{ml}$ of

$15 \cdot 0 \mathrm{U} / \mathrm{ml}$ $5 \cdot 0 \mu \mathrm{g} / \mathrm{ml}$ $2.5 \mu \mathrm{g} / \mathrm{ml}$

$2 \cdot 5 \mu \mathrm{g} / \mathrm{ml}$

$15 \cdot 0 \mathrm{~g}$

$5 \cdot 0 \mathrm{~g}$

$2.5 \mathrm{~g}$

$5.0 \mathrm{~g}$

$0.4 \mathrm{~g}$

$0 \cdot 125 \mathrm{~g}$

1 litre 81 
sterile defibrinated horse blood is added. This is omitted when the broth is to be used for blood culture.

SELECTIVE-ENRICHMENT BROTH

Basal medium as above with the same antibiotics as in the selective blood agar.

\section{Isolation methods}

Specimens from patients are homogenised when necessary and examined by a fluorescent antibody method (FA) for the presence of Legionella ${ }^{8}$ and by Gram's stain for other bacteria. They are then divided into four groups: (1) FA positive: no other organisms seen; (2) FA negative: no other organisms seen; (3) FA positive: other organisms present; (4) FA negative: other organisms present.

Specimens falling into group 1 are inoculated directly on to plates of enriched blood agar and then stored at $+4^{\circ} \mathrm{C}$. The cultures are incubated at $37^{\circ} \mathrm{C}$ in a humid atmosphere containing $5 \%$ carbon dioxide and examined after one, three, and five days' incubation.

When an appreciable number of colonies of other bacteria are present after overnight incubation subsequent growth of Legionella may be inhibited, and the material is re-examined after dilution. In this case three 10 -fold dilutions $(1 / 10,1 / 100$, and $1 / 1000$ ) of the stored specimen are made and used to inoculate further plates of enriched blood agar.

With the exception of blood culture, specimens negative for Legionella by FA and containing no other organisms (group 2) are inoculated into enrichment broth and selective-enrichment broth media in the proportion of 1 part of specimen to 9 parts of medium. Enrichment broth only, without horse blood, is used for blood culture.

Broth cultures are incubated at $37^{\circ} \mathrm{C}$ for one week and inspected daily for turbidity. When this occurs Gram's stain and, when appropriate, fluorescent antibody tests are performed at the same time as subculture to enriched blood agar.

FA positive specimens which are also contaminated with other bacteria (group 3) are inoculated directly on to plates of selective blood agar before and after treatment with acid. Most strains of Legionella grow fairly slowly on this medium, 5-7 days, and cultures are incubated for 10 days before being discarded as negative. For acid decontamination $2 \mathrm{ml}$ of homogenised sample is pipetted into a universal bottle containing $2 \mathrm{ml}$ hydrochloric acid at $\mathrm{pH} 2 \cdot 0$. The mixture is allowed to stand at room temperature for 1 hour and is then neutralised by the addition of $18 \mathrm{ml}$ phosphate buffered saline at pH 7.3. After centrifugation in sealed buckets at
$3000 \mathrm{rev} / \mathrm{min}$ for 20 minutes the supernate is discarded and the sediment is used for inoculating appropriate culture media.

A few of the more grossly contaminated FA positive specimens and all those in group 4 (FA negative: contaminated) are treated with antibiotics as well as decontamination by acid. The sediment obtained after acid treatment is resuspended in $2 \mathrm{ml}$ concentrated antibiotic solution, $1 \mathrm{ml}$ of which is then transferred immediately to $9 \mathrm{ml}$ enrichment broth medium. A second broth is inoculated with the remaining $1 \mathrm{ml}$ of suspension after this has been incubated at $37^{\circ} \mathrm{C}$ for $2-4$ hours. The combination of antibiotics described for the selective media is used but at a concentration 10 times higher.

\section{Results}

The Table shows the results of the examination of material from 10 patients with clinical evidence of Legionnaires' disease from which six strains of L. pneumophila were isolated. Four of the strains were from postmortem lung tissue, one from a bronchial aspirate, one from antemortem blood culture as well as postmortem lung tissue, and all belonged to serogroup 1 . They were first identified by Gram's stain, then by fluorescent antibody staining, and finally by gas liquid chromatography techniques. ${ }^{9}$ All were oxidase and catalase positive, hydrolysed starch but not conventional carbohydrates, and failed to grow on blood or chocolate agar media within seven days.

Five of the specimens (PN1-MN5) were submitted from laboratories out of Nottingham, and only postmortem lung tissue was available for examination. Four were positive by specific fluorescent antibody tests, and Legionella was isolated from three of these. The fifth specimen (MN5) was negative by both methods.

The remaining material was from patients who had been admitted to hospital in Nottingham. Blood cultures were taken into enrichment broth from four patients, two of whom (N6, N7) had already received treatment with antibiotics. $L$. pneumophila was isolated from one of these patients (N10) who died later.

Bronchial aspirates were examined from two patients (N6, N7). Both were FA negative but one was positive by culture. This patient (N7) died 14 days later despite treatment with erythromycin, and his postmortem lung tissue was negative by both FA and cultural methods. In one case (N9), Legionella was isolated from lung despite negative fluorescent antibody tests, but the organism was 
Results of attempted isolation of L. pneumophila from clinical specimens

\begin{tabular}{|c|c|c|c|c|c|c|c|}
\hline \multicolumn{3}{|c|}{ Patient indentification } & \multicolumn{2}{|c|}{ Serological results } & \multicolumn{3}{|l|}{ Specimen details } \\
\hline No. & Se.x & Age & Day of illness & ${ }^{*} I F A$ titre & Specimen & Group & $\begin{array}{l}\text { Isolation of } \\
\text { Legionella }\end{array}$ \\
\hline PN1 & $\mathbf{M}$ & 57 & ? & $<16$ & PM lung & 1 & + \\
\hline MN2 & $\mathbf{M}$ & 51 & 5 & $<16$ & PM lung & 1 & + \\
\hline MN3 & $\mathbf{M}$ & 48 & 20 & 256 & PM lung & 3 & - \\
\hline PN4 & $\mathbf{M}$ & 26 & 10 & 256 & PM lung & 3 & + \\
\hline MN5 & $\mathbf{M}$ & 46 & 10 & $<16$ & PM lung & 4 & - \\
\hline \multirow[t]{2}{*}{ N6 } & $\mathbf{M}$ & 58 & 5 & $<16$ & Blood & 2 & - \\
\hline & & & 15 & 128 & Bronchial aspirate & 4 & - \\
\hline \multirow[t]{2}{*}{ N7 } & $\mathbf{M}$ & 35 & 5 & $<16$ & Blood & 2 & - \\
\hline & & & 15 & 2046 & $\begin{array}{l}\text { Bronchial aspirate } \\
\text { PM lung }\end{array}$ & $\begin{array}{l}4 \\
4\end{array}$ & \pm \\
\hline N8 & $\mathbf{M}$ & 52 & 10 & $<16$ & PM lung & 3 & - \\
\hline N9 & $\mathbf{M}$ & 32 & 5 & $<16$ & Blood & 2 & $\overline{-}$ \\
\hline \multirow[t]{2}{*}{ N10 } & $\mathbf{M}$ & 61 & 5 & $<16$ & Blood & 2 & + \\
\hline & & & & & PM lung & 1 & + \\
\hline
\end{tabular}

*Group 1 formalised yolk sac antigen.

not isolated from a further case (N8) where these were positive.

\section{Discussion}

One of the problems in the laboratory diagnosis of Legionnaires' disease has been the difficulty encountered in culturing the organism from material in which only small numbers are present or which is contaminated with other more rapidly growing bacteria.

At present isolation of $L$. pneumophila from blood and respiratory secretions has been attempted in only a few specialised laboratories, and most cases of human infection have been confirmed retrospectively by serological methods or by demonstration of the organism in postmortem lung tissue. Such tests are tedious and may be technically difficult, the time required for seroconversion may be two weeks or more, and some patients die before antibody is detectable (Table). There is also some degree of uncertainty about the degree of cross reactivity between existing serogroups of Legionella and this, along with the likelihood of further types being described in the future, shows a demonstrable need for simple culture techniques which are suitable for use in routine diagnostic laboratories.

Despite the small number of specimens studied in this series the results appear sufficiently encouraging to merit description of our methods. The enriched blood agar medium has proved superior to those previously described in respect of faster recovery of Legionella and sensitivity to small inocula although both of these features were adversely affected when the selective medium was employed. Other work has shown that iron-sorbitol (Jectofer) and iron-dextran (Imferon) are acceptable as supplementary iron sources, ${ }^{1011}$ and both proved as effective as soluble ferric pyrophosphate provided that a suitable agar base was employed and at least $5 \%$ sterile horse blood was added to the medium. Blood agar base No. 2 (Oxoid) and Columbia agar were both equally suitable and proved markedly superior to several batches of Mueller-Hinton agar.

The enrichment broth medium could detect as few as 5-10 colony forming units of Legionella when inoculated with different strains under laboratory conditions. This produced a readily visible turbidity in the broth after three days' incubation. In contrast to its effect on the enriched blood agar, the antibiotic mixture had little effect on the sensitivity of the broth although growth was delayed by one or two days, depending on the size of the initial inoculum. The recovery of $L$. pneumophila from blood culture by this method should provide a stimulus to further attempts at isolation and perhaps even provide an established procedure for early diagnosis of Legionnaires' pneumonia. In one instance (N9) culture of the organism proved to be the only method by which diagnosis of this infection was confirmed.

I thank Dr AD Macrae for help and encouragement during the preparation of this work and $\mathrm{Mr} \mathrm{G}$ Sharp for technical assistance.

\section{References}

1 Fraser DW, Tsai TR, Orenstein W et al. Legionnaires' disease: description of an epidemic of pneumonia. N Eng J Med 1977;297:1189-97.

2 Jones GL, Hebert GA, eds. "Legionnaires" ": The Disease, the Bacterium and Methodology. Atlanta, Georgia: Center for Disease Control, May 1978.

${ }^{3}$ International symposium on Legionnaires' disease. 
Ann Int Med 1979;90:489-703.

${ }^{4}$ McDade JE, Shepard CC, Fraser DW et al. Legionnaires' Disease: isolation of a bacterium and demonstration of its role in other respiratory disease. $N$ Eng $J$ Med 1977;297:1197-203.

5 Brenner DJ, Steigerwalt AG, Weaver RE, McDade JE, Feeley JC, Mandel M. Classification of the Legionnaires' disease bacterium-an interim report. Curr Microbiol 1978;1:71-5.

${ }^{6}$ Feeley JC, Gorman GW, Gibson RJ. Primary isolation media for a Legionnaires' disease bacterium. In: Jones GL, Hebert GA, eds. "Legionnaires" ": The Disease, the Bacterium and Methodology. Atlanta, Georgia: Center for Disease Control, May 1978; 105-7.
' Greaves PG, Sharp G, Macrae AD. Isolation of 'Legionella pneumophila'. Lancet 1979;1:551 (letter).

${ }^{8}$ Cherry WB, Pittman B, Harris PP et al. Detection of Legionnaires' disease bacteria by direct immunofluorescent staining. J Clin Microbiol 1978;8:329-38.

9 Moss CW, Weaver RE, Dees SB, Cherry WB. Cellular fatty acid composition of isolates from Legionnaires' disease. J Clin Microbiol 1977;6:140-3.

${ }^{10}$ Mitchell RG. 1978; Personal communication.

11 Rutter DA, Maber HB. Culture of Legionella pneumophila. Lancet 1979; $1: 723-4$ (letter).

Requests for reprints to: Mr P Greaves, Public Health Laboratory, University Hospital, Queen's Medical Centre, Nottingham NG7 2UH, UK.

\section{The May 1980 Issue}

\section{THE MAY 1980 ISSUE CONTAINS THE FOLLOWING PAPERS}

Blood rheology JOHN STUART AND MARTIN W KENNY

The red cell osmometer SC ALLEN, IC BALFOUR, AND CC WISE

Fibrin cross-linking in congenital factor XIII deficiency F RODEGHIERO AND T BARBUI

Comparison of three methods for the estimation of plasma antithrombin DS MCLELLAN, JD DEVLIN, GH HEYSE-MOORE, AND A ARONSTAM

Maintenance control of oral anticoagulant therapy by a chromogenic substrate assay for factor $\mathrm{X}$ JG ERSKINE, ISOBEL D WALKER, AND JF DAVIDSON

Extensive bone marrow infarction followed by myelofibrosis in a patient with $\mathrm{Ph}^{\prime}$ positive chronic granulocytic leukaemia BARBARA BAIN

Human lymph node morphology as a function of age and site $P$ LUSCIETI, Th HUBSCHMID, H COTTIER, MW HESS, AND LH SOBIN

Electron microscopical studies of vessels in diabetic peripheral neuropathy ELUNED WILLIAMS, WR TIMPERLEY, JD WARD, AND T DUCKWORTH

Hepatitis in clinical laboratories 1977-78 NR GRIST

Postmortem bacteriology of the lung by printculture of frozen tissue OG ZANEN-LIM AND HC ZANEN
Influence of laboratory reports on prescribing of antimicrobials for urinary tract infection MP BARNES

Detection of virus particles by electron microscopy with polyacrylamide hydrogel HILARY J WHITBY AND FG RODGERS

HLA-B8, immunoglobulins, and antibody responses in alcohol-related liver disease MY MORGAN, MGR ROSS, CM NG, DM ADAMS, HC THOMAS, AND SHEILA SHERLOCK

Multiple on-line data collection and processing for radioimmunoassay using a micro-computer system N WYNNE CARTER, D DAVIDSON, DF LUCAS, AND PD GRIFFITHS

Detection of monoclonal immunoglobulins by immunoelectrophoresis: a possible source of error AM SMITH, RA THOMPSON, AND MR HAENEY

\section{Technical method}

A simple procedure for the preparation of rosetted cells for electron microscopy CM PAYNE AND VF SATTERFIELD

Letters to the Editor

Book reviews

Copies are still available and may be obtained from the PUBLISHING MANAGER, BRITISH MEDICAL ASSOCIATION, TAVISTOCK SQUARE, LONDON WC1H 9JR, price $£ 3.00$, including postage 